\title{
Long Noncoding RNA KIAA0125
}

National Cancer Institute

\section{Source}

National Cancer Institute. Long Noncoding RNA KIAA0125. NCI Thesaurus. Code C131758.

Long noncoding RNA KIAA0125 ( 10 kb) is encoded by the human FAM30A gene. This non-coding RNA may be involved in the modulation of both cell migration and epithelialmesenchymal transition. 